\title{
Influence of unilateral ovariectomy performed before ovulation on ovarian function, steroid hormone levels and development of porcine fetuses
}

\author{
Klaus-Peter Brüssow ${ }^{1,2}$, Jozsef Rátky ${ }^{3}$, \\ Bartosz Kempisty ${ }^{4,5}$, Paweł Antosik ${ }^{1}$, Magdalena Herudzińska ${ }^{1}$ \\ and Jędrzej Maria Jaśkowski ${ }^{1}$ \\ ${ }^{1}$ Centre of Veterinary Sciences, Nicolaus Copernicus University, Torun, Poland \\ ${ }^{2}$ Institute of Reproductive Biology, Leibniz Institute of Farm Animal Biology, \\ Dummerstorf, Germany \\ ${ }^{3}$ Department and Clinic of Reproduction, University of Veterinary Medicine, \\ Budapest, Hungary \\ ${ }^{4}$ Department of Histology and Embryology, ${ }^{5}$ Department of Anatomy, \\ Poznań University of Medical Sciences, Poznań, Poland
}

\section{Corresponding author}

Prof. Dr. Dr. h.c. Klaus-Peter Brüssow

Centre of Veterinary Sciences, Nicolaus Copernicus University

ul. Gagarina 7, 87-100 Toruń, Poland

E-mail: brussow@umk.pl; prof.bruessow@gmail.com 


\begin{abstract}
Corpus luteum (CL) activity is closely linked with initiation and maintenance of pregnancy and with fetal development. The present study was aimed to analyze the impact of unilateral ovarian removal on ovarian function, steroid hormone level and fetal distribution and development. Unilateral ovariectomy (uni-OVX) was performed in gilts one day before ovulation (group SHORT, $\mathrm{n}=24$ ), 20 days before subsequent ovulation (group LONG, $\mathrm{n}=23$ ) or ovaries remained intact (group INTACT, $\mathrm{n}=22$ ). Gilts were inseminated by single fixed-time laparoscopic intrauterine insemination (LIUI) after hormonal estrus synchronization. Two days before the end of a 15 day long altrenogest feeding, a part of gilts $(n=23)$ were surgically fitted with a jugular vein catheter and blood samples were collected to determine of estradiol (E2) and progesterone (P4) concentrations. All animals were slaughtered on day 30 of gestation and ovarian features as well as the number, weight and distribution of fetuses recorded. Altogether, 48 gilts (70\%) were pregnant and pregnancy rates did not differ between groups. Short term uni-OVX affected CL number compared to intact and long term OVX gilts $(9.9 \pm 0.8$ vs. $20.6 \pm 1.9$ and $17.5 \pm 0.8 ; \mathrm{P}<0.05)$ and the number of fetuses $(8.7 \pm 0.5$ vs. $15.0 \pm 1.0$ and $14.4 \pm 1.1$; $\mathrm{P}<0.05)$, respectively. Weights of individual CL were not influenced by treatment. Fetuses were differently distributed in the uterine horns after uni-OVX. A higher $(\mathrm{P}<0.05)$ proportion of fetuses was present always in the horn which bore the ovary. In all groups, weights of fetuses from uterine horns with an active ovary was similar; however, fetuses of the OVX horn of the SHORT group were lighter $(\mathrm{P}<0.05)$. Steroid hormone profile was typical for pregnant gilts, but differences were observed between groups. Both, the preovulatory E2 concentrations and the early luteal phase $\mathrm{P} 4$ levels were higher $(\mathrm{P}<0.05)$ in gilts of the INTACT and LONG groups. In summary, compared to intact gilts, only long term uni-OVX could compensate ovarian development. Short term uni-OVX affects (1) the total number of CL and fetuses, (2) the distribution and weight of fetuses in the uterine horns and (3) steroid hormone levels. Therefore, the time window, but not the uni-OXV per se, which alters the local supply of progesterone, has an impact on fetal development and survival.
\end{abstract}

Keywords: unilateral ovariectomy; corpus luteum; fetus; steroid hormone; pig.

\title{
Introduction
}

Ovarian compensatory hypertrophy in pigs after unilateral ovariectomy (uni-OVX) has been studied already two centuries ago [1] and is still an interesting current model to study follicle selection and embryo survival [2-4]. Since the corpora lutea (CL) are a considerable source of progesterone (P4) in the pig to establish and, in some extent, to maintain pregnancy, their influence on embryo survival was analyzed, previously [4]. 
In this study uni-OVX was employed on day $5 / 6$ of the luteal phase, i.e. about 15 days before subsequent ovulation and insemination. They hypothesized that the remaining ovary (CL) had an impact on embryo survival in the ovariectomized uterine horn. Since in the mentioned study OVX was performed in a time window which allowed compensating follicle/CL development, our study was aimed to compare the influence of different time points of uni-OVX on ovarian development, growth and distribution of fetuses within uterine horns as well as on steroid hormone secretion.

\section{Material and Methods}

Animals and experimental design: All procedures involving animal handling and treatment were approved by the Ethic Committee for Animal Use and Care. Altogether, 69 puberal German Landrace gilts at the age of nine months and with mean body weights of $142 \pm 7 \mathrm{~kg}$ were included in the study. Estrus was synchronized in all gilts by 15-day long feeding of altrenogest (16 mg altrenogest/day/ gilt; Regumate ${ }^{\oplus}$, Janssen-Cilag $\mathrm{GmbH}$, Neuss, Germany). Twenty-four hours after the last altrenogest feeding (08:00 h), each animal received a single intramuscular injection of 850 IU equine chorionic gonadotropin (eCG; Pregmagon ${ }^{\circledR}$, IDT Biologika, Dessau-Tornau, Germany). Ovulation was induced 80 h later by administration of $50 \mu \mathrm{g} \mathrm{GnRH}$ agonist (Gonavet Veyx ${ }^{\oplus}$, Veyx-Pharma $\mathrm{GmbH}$, Schwarzenborn, Germany). Gilts were assigned to three different groups: (1) controls ( $\mathrm{n}=22$, group INTACT), (2) gilts underwent unilateral ovariectomy (uni-OVX) one day before expected ovulation $(\mathrm{n}=24$, group SHORT) and (3) gilts with uni-OVX long, i.e., 20 days before subsequent ovulation ( $\mathrm{n}=23$, group LONG).

Unilateral ovariectomy (uni-OVX): Ovariectomy was performed by mid-ventral laparotomy under general anesthesia induced with ketamine $\left(0.15 \mathrm{ml} / \mathrm{kg} \mathrm{BW}\right.$, Ursotamin ${ }^{\oplus}$, Serumwerk Dessau, Germany) and azaperone $\left(0.03 \mathrm{ml} / \mathrm{kg}\right.$ BW, Stresnil ${ }^{\oplus}$, Elanco Animal Health, Bad Homburg, Germany). Ovarian blood supply was ligated in one ovary and it was removed 
by electrocautery (ICC 50, ERBE Elektromedizin, Tübingen, Germany). The wound was closed by adapting peritoneum, musculature and cutis separately. OVX was performed shortly before ovulation, i.e., $31 \mathrm{~h}$ after $\mathrm{GnRH}$ and immediately before insemination (group SHORT) or one day before the first altrenogest feeding, i.e. 20 days before expected ovulation (group LONG).

Laparoscopic intrauterine insemination (LIUI): All gilts were inseminated laparoscopically $31 \mathrm{~h}$ after $\mathrm{GnRH}$ application with $20 \mathrm{ml} /$ uterine horn of extended, fresh boar semen $(30 \times 106$ sperm cells $/ \mathrm{ml} ; 65 \%$ motility) as described previously [5-6]. Anaesthetized gilts were fixed in a dorsal position. A pneumoperitoneum with $\mathrm{CO} 2$ was automatically produced (Endo Tech, Munich, Germany). Thereafter, three trocar cannulas (Storz, Tuttlingen, Germany) were inserted into the abdomen for optics (ETB, Berlin, Germany) and grasping forceps (NeoMed, Gutach/Bleibach, Germany). All laparoscopic handling was observed on a video monitoring system (NeoMed, Gutach/Bleibach, Germany). For insemination, the uterine horn was carefully fixed with atraumatic forceps, and the uterine wall was punctured approximately $10 \mathrm{~cm}$ caudal from the uterotubal junction with a trocar, $2.5 \mathrm{~mm}$ in diameter. Under visual control, a 2.2- $\mathrm{mm}$ catheter (RÜSCH feeding tube, W. Rüsch AG, Kernen, Germany) connected to a $20 \mathrm{ml}$ syringe was inserted through the trocar cannula about $3 \mathrm{~cm}$ into the uterine lumen in the direction towards the tip of the uterine horn, and then semen was deposited. The insemination procedure was repeated at the opposite uterine horn.

Catheterisation and blood sampling: Two days before the end of the altrenogest feeding, a silicon catheter $(1.6 \mathrm{~mm}$ ID, $3.2 \mathrm{~mm}$ OD, AMT, Düsseldorf, Germany) was inserted into the Vena jugularis of 23 gilts (INTACT, $\mathrm{n}=8$; SHORT, $\mathrm{n}=8$; LONG, $\mathrm{n}=7$ ) as described previously [7]. Blood samples (each $5 \mathrm{ml}$ ) were collected in heparinized tubes (SARSTEDT, Nürnbrecht, Germany) three times a day (08:00, 12:00 and 16:00) on days 1 to 23 after altrenogest feeding (day -5 to 17 of gestation) and additionally in 4 h-intervals on gestation days $0-1$ and $13-15$, respectively. The blood samples were centrifuged immediately at $1,800 \mathrm{~g}$ for $15 \mathrm{~min}$. The plasma samples were pipetted into tubes and stored at $-20^{\circ} \mathrm{C}$ 
until use. After every blood collection, the catheter was filled with $3 \mathrm{ml}$ of $3 \% \mathrm{Na}$-citrate. Prior to blood collection, the citrate within the catheter together with the first $3 \mathrm{ml}$ of blood was discharged.

Progesterone and estradiol $17 \beta$ assays: The plasma concentrations of progesterone (P4) were measured by a direct $3 \mathrm{H}$-RIA in $10-\mu \mathrm{l}$ duplicates as described previously [8]. The range of the standard curve was from 6.25 to $1,600 \mathrm{pg} / \mathrm{ml}$. The incubation steps were performed at $37^{\circ} \mathrm{C}$ for $30 \mathrm{~min}$ and at $4{ }^{\circ} \mathrm{C}$ for $2 \mathrm{~h}$. The $\mathrm{B} / \mathrm{F}$ separation was performed by the dextran-charcol method. Counting of radioactivity was made by a Liquid Scintillation Counter with integrated RIA program (Tri-Carb 2900TR, Perkin-Elmer, Rodgau, Germany). The intra- and interassay CVs were 7.6 and $9.8 \%$, respectively.

The analysis of plasma estradiol (E2) was performed by a modified 3H-RIA after ethyl ether extraction of $100 \mu \mathrm{l}$ samples in duplicates [9]. The antibody raised in rabbits and purified by chromatography was used at a titre of $1: 55,000$ together with $[2,4,6,7-3 \mathrm{H}]$-estradiol $17 \beta$ (GE Healthcare, Freiburg, Germany). Incubation steps and counting procedure were the same as for P4. The sensitivity of the RIA was $3 \mathrm{pg} / \mathrm{ml}$. The intra- and inter-assay CVs were 6.9 and 9.9\%, respectively.

Animal slaughter and measurements: Gilts were slaughtered on day 30 of gestation and the reproductive tract was removed. Thereafter, the number of corpora lutea (CL) and fetuses was counted, and the weight of ovaries, of individual CL, and of uterus and fetuses was recorded. Thereby, it was distinguished between the uterine horn having an ovary and the opposite one, where the ovary had been ectomized.

Statistical analysis: Calculation of means and their standard deviation and analyses of differences in mean values between groups was carried using the software package SigmaPlot 11.0. Data were analyzed by One Way ANOVA and differences of $\mathrm{P}<0.05$ were considered as significant. 


\section{Results}

Altogether, 48 gilts were pregnant after LIUI and pregnancy rate did not differ between groups (INTACT $-63.6 \%$, SHORT $-70.8 \%$ and LONG $73.9 \%$, respectively, $\mathrm{P}>0.05)$. Differences were obtained regarding the number of CL (Table 1). In gilts of the LONG group, the remaining ovary revealed a significant higher number $(\mathrm{P}<0.05)$ compared to that of the ovaries of the other groups, however, it was similar to the total CL number in the control (INTACT) group. The total CL weight was different; however, the calculated mean weight of an individual CL and the CL weight per fetus did not differ between groups $(\mathrm{P}>0.05)$. Also, the number of fetuses differed (Table 2). In the SHORT group, the total number of fetuses, as well as the number of fetuses in the discrete uterine horns was lower $(\mathrm{P}<0.05)$ compared to the INTACT and LONG groups. Comparing the distribution of fetuses in the uterine horns, in both uni-OVX groups a significant higher $(\mathrm{P}<0.05)$ percent was observed always in that horn bearing the ovary.

Differences in fetus weight were also found (Table 3). Total weight of fetuses was lower $(\mathrm{P}<0.05)$ in the SHORT compared to the LONG group. However, in the uterine horn with an ovary, the weight of fetuses was identical in all groups, but in the OVX side of the SHORT group it was lower $(\mathrm{P}<0.05)$ compared to the respective INTACT and LONG groups, and to its opposite uterine horn. Embryo mortality did not differ between groups $(\mathrm{P}>0.05)$ and was $24 \%$ (INTACT), 19\% (SHORTT) and $14 \%$ (LONG), respectively. 
Table 1. Numbers and weights of corpora lutea $(\mathrm{CL})$ and numbers of fetuses in intact (INTACT) and short (SHORT) or long term before ovulation (LONG) unilateral ovariectomized gilts

\begin{tabular}{|c|c|c|c|c|c|c|}
\hline \multirow{2}{*}{ Group } & $\begin{array}{c}\text { Pregnant } \\
\text { gilts (n) }\end{array}$ & $\begin{array}{c}\text { Corpora } \\
\text { lutea } \\
(\mathbf{n})\end{array}$ & $\begin{array}{c}\text { Total CL } \\
\text { weight } \\
(\mathbf{g})\end{array}$ & $\begin{array}{c}\text { Weight / CL } \\
(\mathbf{g})\end{array}$ & $\begin{array}{c}\text { Number } \\
\text { of fetuses }\end{array}$ & $\begin{array}{c}\text { CL weight / } \\
\text { fetus } \\
(\mathbf{g})\end{array}$ \\
\cline { 3 - 7 } & means \pm SE & means \pm SE & means \pm SE & means \pm SE & means \pm SE \\
\hline INTACT & 14 & $20.6 \pm 1.9^{\mathrm{a}}$ & $10.65 \pm 0.81^{\mathrm{a}}$ & $0.48 \pm 0.03$ & $15.0 \pm 1.0^{\mathrm{a}}$ & $0.65 \pm 0.05$ \\
\hline ipsilateral & & $9.9 \pm 0.8^{\mathrm{b}}$ & $4.66 \pm 0.37^{\mathrm{b}}$ & & & \\
\hline contrala- & & $10.5 \pm 1.3^{\mathrm{b}}$ & $5.99 \pm 0.68^{\mathrm{b}}$ & & & \\
\hline teral & 17 & $10.9 \pm 0.7^{\mathrm{b}}$ & $5.83 \pm 0.24^{\mathrm{b}}$ & $0.56 \pm 0.03$ & $8.7 \pm 0.5^{\mathrm{b}}$ & $0.69 \pm 0.05$ \\
\hline SHORT & 17 & $17.5 \pm 0.8^{\mathrm{a}}$ & $9.38 \pm 0.56^{\mathrm{a}}$ & $0.55 \pm 0.03$ & $14.4 \pm 1.1^{\mathrm{a}}$ & $0.68 \pm 0.05$ \\
\hline LONG & 17 & & & & \\
\hline
\end{tabular}

${ }^{\mathrm{a}, \mathrm{b}} P<0.05$, Means \pm SE with different superscripts differ within a column

Table 2. Numbers and distribution of fetuses in the OVX- and opposite uterine horn of intact (INTACT) and short (SHORT) or long term before ovulation (LONG) unilateral ovariectomized gilts

\begin{tabular}{|c|c|c|c|c|c|c|}
\hline \multirow{2}{*}{ Group } & \multirow{2}{*}{ Gilts (n) } & \multicolumn{4}{|c|}{ Embryos per uterine horn } \\
\cline { 3 - 7 } & & Total & \multicolumn{2}{|c|}{ OVX-horn ${ }^{\#}$} & \multicolumn{2}{c|}{ Opposite horn $^{*}$} \\
\hline & & means \pm SE & means \pm SE & $\%$ & means \pm SE & $\%$ \\
\hline INTACT & 14 & $15.0 \pm 1.0^{\mathrm{a}}$ & $7.7 \pm 0.6^{\mathrm{a}}$ & $51.3 \pm 1.7^{\mathrm{a}}$ & $7.3 \pm 0.6^{\mathrm{a}}$ & $48.6 \pm 1.7^{\mathrm{a}}$ \\
\hline SORTT & 17 & $8.7 \pm 0.5^{\mathrm{b}}$ & $4.4 \pm 0.4^{\mathrm{b}}$ & $44.1 \pm 3.9^{\mathrm{A}}$ & $4.4 \pm 0.4^{\mathrm{b}}$ & $55.9 \pm 3.8^{\mathrm{B}}$ \\
\hline LONG & 17 & $14.4 \pm 1.1^{\mathrm{a}}$ & $6.1 \pm 0.8^{\mathrm{A}}$ & $39.5 \pm 3.8^{\mathrm{b}, \mathrm{A}}$ & $8.9 \pm 0.5^{\mathrm{a}, \mathrm{B}}$ & $60.5 \pm 3.8^{\mathrm{b}, \mathrm{B}}$ \\
\hline
\end{tabular}

\# in the INTACT group, the data are respective for the ipsi- and contralateral uterine horn

${ }_{\mathrm{A}, \mathrm{B}} P<0.05-$ Means \pm SE with different superscripts differ between the uterine horns with and without an ovary

${ }^{\mathrm{a}, \mathrm{b}} P<0.05-$ Means \pm SE with different superscripts differ between groups 
Table 3. Numbers and weights of fetuses in uterine horns of intact (INTACT) and short (SHORT) or long term before ovulation (LONG) unilateral ovariectomized gilts

\begin{tabular}{|c|c|c|c|c|c|c|}
\hline \multirow{2}{*}{ Group } & \multicolumn{3}{|c|}{ Fetuses (n) } & \multicolumn{3}{c|}{ Fetus weight (g) } \\
\cline { 2 - 7 } & total & $\begin{array}{c}\text { OVX- } \\
\text { horn }\end{array}$ & $\begin{array}{c}\text { Opposite } \\
\text { horn }\end{array}$ & total & OVX-horn & $\begin{array}{c}\text { Opposite } \\
\text { horn }^{*}\end{array}$ \\
\hline INTACT & 210 & 108 & 102 & $1.41 \pm 0.02$ & $1.39 \pm 0.03^{\mathrm{A}}$ & $1.43 \pm 0.02$ \\
\hline SHORT & 148 & 71 & 77 & $1.38 \pm 0.02^{\mathrm{A}}$ & $1.32 \pm 0.03^{\mathrm{a}, \mathrm{B}}$ & $1.43 \pm 0.02^{\mathrm{b}}$ \\
\hline LONG & 255 & 111 & 144 & $1.44 \pm 0.01^{\mathrm{B}}$ & $1.46 \pm 0.02^{\mathrm{A}}$ & $1.43 \pm 0.02$ \\
\hline
\end{tabular}

\# in the INTACT group, the data are respective for the ipsi- and contralateral uterine horn ${ }^{\mathrm{A}, \mathrm{B}} P<0.05$, Means $\pm \mathrm{SE}$ with different superscripts differ within a column

${ }^{\mathrm{a}, \mathrm{b}} P<0.05$, Means \pm SE with different superscripts differ within a row

Table 4. Numbers of corpora lutea and concentrations of preovulatory estradiol and early luteal phase progesterone in intact (INTACT) and short (SHORT) or long term before ovulation (LONG) unilateral ovariectomized gilts

\begin{tabular}{|c|c|c|c|c|}
\hline \multirow{2}{*}{ Group } & \multirow{2}{*}{ Gilts (n) } & Corpora lutea & Estradiol (pg/ml) & Progesterone $(\mathrm{ng} / \mathrm{ml})$ \\
\hline & & means $\pm \mathrm{SE}$ & means $\pm \mathrm{SE}$ & means $\pm \mathrm{SE}$ \\
\hline INTACT & 4 & $20.6 \pm 1.9$ & $6.11 \pm 0.28$ & $4.22 \pm 0.52^{\mathrm{a}}$ \\
\hline SHORT & 6 & $10.9 \pm 0.7$ & $5.74 \pm 0.36^{\mathrm{a}}$ & $2.91 \pm 0.47^{\mathrm{b}, \mathrm{A}}$ \\
\hline LONG & 6 & $17.5 \pm 0.8$ & $8.40 \pm 0.77^{\mathrm{b}}$ & $4.44 \pm 0.69^{\mathrm{B}}$ \\
\hline
\end{tabular}

${ }^{\mathrm{a}, \mathrm{b}} P<0.05$, Means \pm SE with different superscripts differ within a column; ${ }^{\mathrm{A}, \mathrm{B}} P=0.06$

Pregnant gilts revealed a typical steroid hormone pattern (Figure 1). However, differences were observed between groups regarding estradiol and progesterone. The preovulatory E2 concentrations (day 1-5 after altrenogest) were higher $(\mathrm{P}<0.05)$ in the INTACT and LONG groups compared to SHORT (Table 4). Also, the early luteal phase P4 levels (day 0-5 of gestation) differed between these groups. 

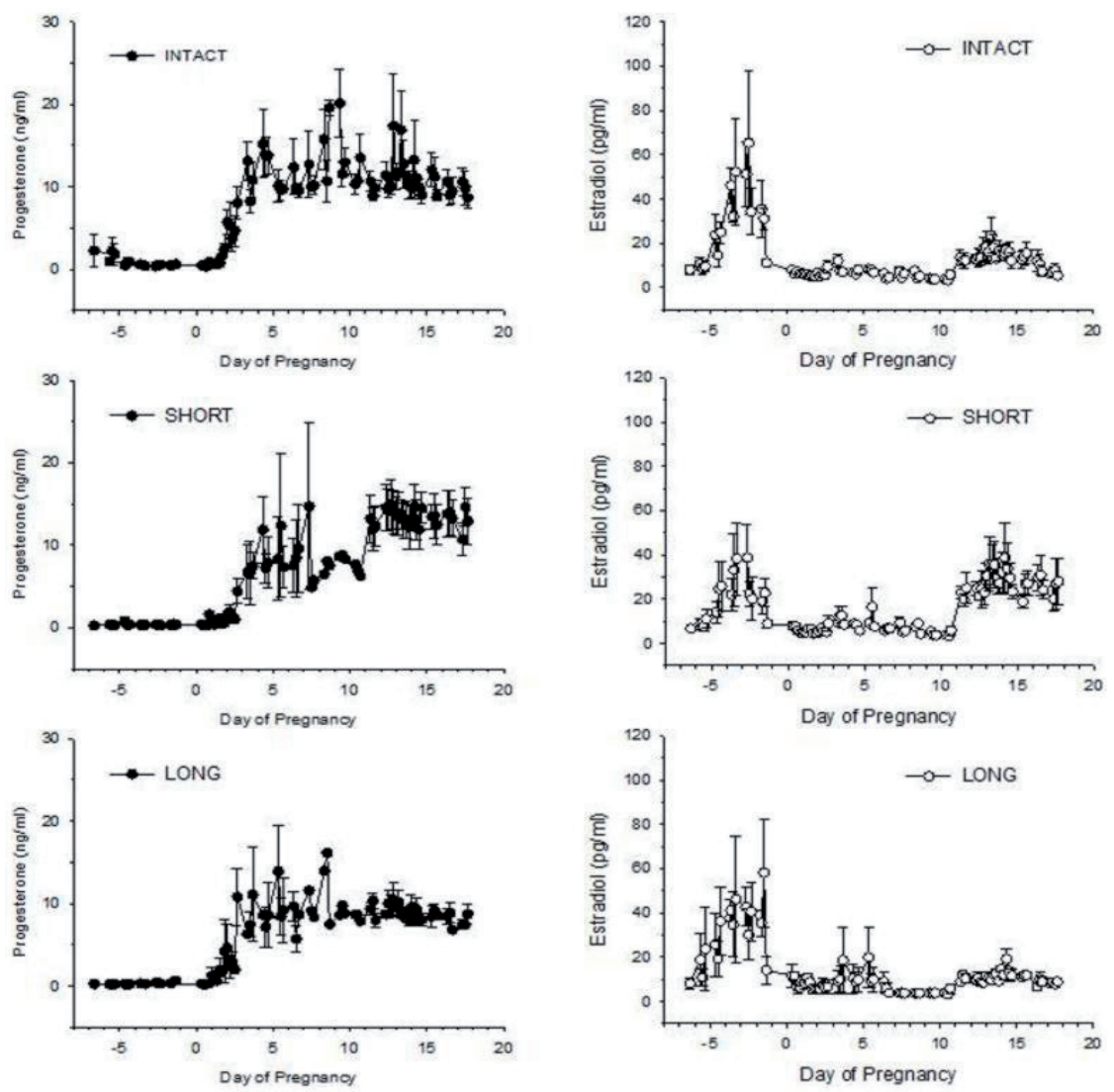

Figure 1. Mean ( $\pm \mathrm{SE}$ ) progesterone $(\mathrm{ng} / \mathrm{ml})$ and estradiol $17 ß(\mathrm{pg} / \mathrm{ml})$ concentrations in intact (INTACT) and short (SHORT) or long term before ovulation (LONG) unilateral ovariectomized gilts

\section{Discussion}

Our results confirm previous data that the time point of uni-OVX influences ovarian follicle compensation. Ovariectomy long time $[4,10]$ but not immediately before ovulation permits compensation of follicle recruitment $[2,11]$. In our study, uni-OVX 20 days before subsequent 
ovulation allowed the remaining ovary to compensate the number of CL (17.5 \pm 0.8$)$ similar to the control group (20.6 \pm 1.9$)$. Similar, Knight et al. [10] observed $13.0 \pm 1.9$ vs. $11.8 \pm 0.9$ CL and Athorn et al. [4] $15.9 \pm 0.8$ vs. $15.7 \pm 0.6 \mathrm{CL}$, respectively. However, uni-OVX immediately before ovulation significantly decreased the number of CL $(10.9 \pm 0.7)$ similarly to $9.5 \pm 1.2$ vs. $14.1 \pm 1.2$ in the study of Clark et al. [2].

In our study, there was no influence of uni-OVX on CL weights. Although, the total CL weight was higher in gilts of the INTACT and LONG groups due to the significant higher CL number, the mean individual CL weights were in the range of 0.48 to $0.56 \mathrm{~g}$ and did not differ between groups. In previous experiments [12-15] similar CL weights were reported for intact gilts $(0.42,0.53,0.55$ and $0.42 \mathrm{~g}$, respectively). However in the study of Athorn et al. [4] the individual CL weight was higher in the ectomized groups $(0.50-0.47 \pm 0.02 \mathrm{~g})$.

Since periovulatory uni-OVX did not compensate the number of CL, the number of fetuses was significantly reduced in the SHORT group, respectively. However, the calculated CL weight per fetus was not different between the control and uni-OVX groups. It can be argued that CL weight (and probably the steroid production of CL) is not close related to the number of fetuses and a threshold of CL is sufficient to maintain pregnancy. For instance, no correlation was observed between the number of CL and plasma progesterone concentrations when more than five CL were present $[16,17]$. As well, partial and stepwise lutectomy to a certain degree did not affect progesterone secretion and pregnancy $[18,19]$. Also Athorn et al. [4] did not find a relationship between luteal weights and systemic P4 levels.

Fetuses were distributed equally in the uterine horns of the INTACT group; however, in the uni-OVX gilts a significantly higher proportion of fetuses were in the horn bearing the ovary. This was also stated in the study of Athorn et al. [4]. The presence of the ovary and its local supply of $\mathrm{P} 4$ can favor the environment of the appendant uterine horn for implantation of embryos and fetal development. As previously reported [20,21], the local counter current transfer of P4 from ovar- 
ian veins to uterine arteries as well as the transport via the lymphatic system benefits the supply of $\mathrm{P} 4$ to the uterus and on this way pregnancy. The positive effect of the ovary was also visible with regard to fetal weight. In all groups, identical fetus weights were recorded in the uterine horn which bears the ovary. Furthermore, only in the SHORT group, the mean weight of fetuses from the OVX-compared to the opposite horns was lower. Such lower weight was also found comparing the OVX-horns of both ovariectomized groups. Lower weight of fetuses $(-12 \%)$ in the OVX-horn was also reported by Athorn et al. [4].

Steroid hormones play a crucial role during pregnancy. Progesterone of luteal origin is involved in endometrial differentiation and cell proliferation, and has a stimulatory effect on uterine secretion of different compounds [22-24]. The progesterone concentration curve obtained in the present experiment was similar to that detected in previous studies in pregnant pigs [25-28]. However, the lower number of CL after uni-OVX in the SHORT group influenced the progesterone levels during the early luteal phase (SHORT < INTACT, P < 0.05; SHORT < LONG, P = 0.06). Little change in plasma $\mathrm{P} 4$ was also observed following uni-OVX in previous study [18] and the absence of CL significantly effected progesterone concentrations in the ovarian and uterine veins of the ovariectomized uterine side [29]. Uni-OVX effected also the preovulatory E2 concentration in the SHORT group. To our knowledge, there are no experimental data on E2 concentrations in the peripheral plasma after ULO. However, Kramer and Lamberson [13] reported significantly lower estrogen concentration in the follicular fluid after short term vs. long term uni-OVX and controls, respectively.

In summary, compared to intact gilts, the development of the remaining ovary could be compensated only when uni-OVX was performed considerably before subsequent ovulation. Unilateral OVX shortly before ovulation affects (1) the total number of CL and fetuses, (2) the distribution and weight of fetuses in the uterine horns and (3) steroid hormone levels. Therefore, the time window, but not the unilat- 
eral ovariectomy per se, which alters the local supply of progesterone, has an impact on fetal development and survival.

\section{Abbreviations:}

List of abbreviation: $\mathrm{CL}=$ corpus luteum, $\mathrm{eCG}=$ equine chorionic gonadotropin, $\mathrm{E} 2$ = estradiol $\mathrm{GnRH}=$ gonadotropin releasing hormone, LIUI = laparoscopic intrauterine insemination, IU = international unit, $\mathrm{P} 4=$ progesterone uni-OVX = unilateral ovariectomy, vs. = versus

\section{Acknowledgements}

Partially supported of the Polish National Center of Science (Grant OPUS No. 2011/03/B/NZ4/02411). The authors appreciate the laboratory help of Mrs. S. Rodewald and Mrs. V. Tesch.

\section{References}

1. Athorn RZ, Stott P, Bouwman EG, Ashman R, O'Leary S, Nottle M, Langendijk P Direct ovarian-uterine transfer of progesterone increases embryo survival in gilts. Reprod Fertil Dev. 2011;23:921-928.

2. Athorn RZ, Stott P, Bouwman EG, Chen TY, Kennaway DJ, Langendijk P Effect of feeding level on luteal function and progesterone concentration in the vena cava during the early pregnancy in gilts. Reprod Fertil Dev.ment 2013;25:531538.

3. Brüssow K-P, Schneider F, Kanitz E, Otten W, Tuchscherer M Alteration of reproductive hormone levels in pregnant sows induced by repeated ACTH application and its possible influence on pre- and post-natal hormone secretion of piglets. J Reprod Dev. 2005;51:133-142. 
4. Brüssow K-P, Torner H, Ratky J, Manabe N, Tuchscherer A Experimental evidence for the influence of cumulus-oocyte-complexes on sperm release from the porcine oviductal sperm reservoir. Reprod Fertil Dev. 2006;52:249-257.

5. Brüssow K-P, Torner H, Ratky J Sperm migration in pigs after deep intrauterine and intraperitoneal insemination. Reprod Fertil Dev. 2011;57:342-345.

6. Brüssow K-P, Vernunft A, Kempisty B, Rátky J Single fixed-time laparoscopic intrauterine insemination as a tool to obtain low-diversity porcine embryos. Vet Medicina. 2013;58:412-416.

7. Clark JR, Brazier SG, Wiginton LM, Stevenson GR, Tribble LF Time of ovarian follicle selection during the porcine estrus cycle. Theriogen. 1982;18:697709.

8. Coleman DA, Fleming MW, Dailey RA Factors affecting ovarian compensation after unilateral ovariectomy in gilts. J Anim Sci. 1984;59:170-176.

9. Estienne MJ, Harper AF, Estienne CE Effects of dietary supplementation with omega-3 polyunsaturated fatty acids on some reproductive characteristics in gilts. Reprod Biol. 2006;6:231-241.

10. Guthrie HD, Henricks DM, Handlin DL Plasma estrogen, progesterone and luteinizing hormone prior to estrus and during early pregnancy. Endocrin. 1972;1:675-679.

11. Hunter J An experiment to determine the effect of extirpating one ovarium upon the number of young produced. Phil Transac. 1987;77:233-239.

12. Knight JW, Bazer FW, Thatcher WW, Franke DE, Wallace DE Conceptus development in intact and unilaterally hysterectomized-ovariectomized gilts: Interrelation among hormonal status, placental development, fetal fluids and fetal growth. J Anim Sci. 1977;44:620-637.

13. Kramer KK, Lamberson WR Long term effects of unilateral ovariectomy on ovarian function in gilts. Anim Reprod Sci. 1991;26:137-149.

14. Martin MJ, Redmer DA, Ford JJ, Christenson RK, Day BN Ovarian compensatory hypertrophy following unilateral ovariectomy in the suckled sow. J Anim Sci. 1986;63:572-578.

15. Nase BR, Hagen DR, Kavanaugh JF, Griel LC Effect of partial stepwise luteectomy in pregnant gilts on maternal and fetal concentrations of progesterone. Biol Reprod. 1985;33:88-92. 
16. Peltoniemi OAT, Easton BG, Love RJ, Klupiec C, Evans G Effect of chronic treatment with a GnRH agonist (Goserelin) on LH secretion and early pregnancy in gilts. Anim Reprod Sci. 1995;40:121-133.

17. Persson E, Sahlin L, Masironi B, Dantzer V, Eriksson H, Rodriguez-Martinez $\mathrm{H}$ Insulin-like growth factor-I in the porcine endometrium and placenta: localization and concentration in relation to steroid influence during early pregnancy. Anim Reprod Sci. 1997;46:261-281.

18. Pharazyn A, Foxcroft GR, Aherne FX Temporal relationship between plasma progesterone concentrations in the utero-ovarian and jugular veins during early pregnancy in the pig. Anim Reprod Sci. 1991;26:323-332.

19. Rodriguez $\mathrm{H}$, Kunavongkrit A Chronical venous catheterization for frequent blood sampling in unrestrained pigs. Acta Vet Scand. 1983;24:318-320.

20. Schneider F, Brüssow K-P Effect of preovulatory administered depot gonadotropin-releasing hormone agonist on reproductive hormone levels and pregnancy outcome in gilts. Reprod Fertil Dev. 2006;18:857-866.

21. Schneider F, Heleil B, Alm H, Torner H, Becker F, Viergutz T, Nürnberg G, Kanitz W Endocrine, morphological, and cytological effects of a depot $\mathrm{GnRH}$ agonist in bovine. Anim Reprod Sci. 2006;92:9-28.

22. Spies HG, Zimmermann DR, Self HL, Casida LE Effect of exogenous progesterone on the corpora lutea of hysterectomized gilts. J Anim Sci. 1960;19:101108.

23. Stefanczyk-Krzymowska S, Skipor J, Grzegorzewski W, Wasowska B, Krzymowski T Local increase of steroid hormone concentrations in blood supplying the uterus and oviduct in anaesthetized and conscious gilts. Anim Reprod Sci. 1994;37:35-41.

24. Stefanczyk-Krzymowska S, Krzymowski T Local adjustment of blood and lymph circulation in the hormonal regulation of reproduction in femal pigs - facts, conclusions and suggestions for future research. Reprod Biol. 2002;2:115-132.

25. Thomford PJ, Sander HK, Kendall JZ, Sherwood OD, Dziuk PJ Maintenance of pregnancy and levels of progesterone and relaxin in the serum of gilts following a stepwise reduction in the number of corpora lutea. Biol Reprod. 1984;31:494-498.

26. Vallet JL, Christenson RK, Trout WE, Klemcke HG Conceptus, progesterone, and breed effects on uterine protein secretion in swine. J Anim Sci. 1998;76:2657-2670. 
27. Virolainen JV, Love RJ, Tast A, Peltoniemi OAT Effect of a gonadotrophin-releasing hormone antagonist on luteinizing hormone secretion and early pregnancy in gilts. Reprod Fertil Dev. 2003;15:451-459.

28. Webel SK, Reimers TJ, Dziuk PJ The lack of relationship between plasma progesterone levels and number of embryos and their survival in the pig. Biol Reprod. 1975;13:177-186.

29. Wollenhaupt K, Kettler A, Brüssow K-P, Schneider F, Kanitz W, Einspanier R Regulation of the expression and bioactivation of the epidermal growth factor receptor system by estradiol in pig oviduct and endometrium. Reprod Fertil Dev. 2001; 13:167-176. 